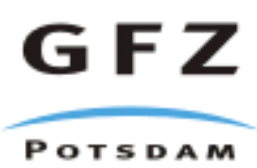

Originally published as:

Stankiewicz, J., Ryberg, T., Schulze, A., Lindeque, A., Weber, M. H., de Witt, M. J. (2007): Initial results from wide-angle seismic refraction lines in the southern Cape. - South African Journal of Geology, 110, 2-3, 407-418

DOI: 10.2113/gssajg.110.2-3.407 


\title{
Initial results from wide-angle seismic refraction lines in the southern Cape
}

\author{
J. Stankiewicz, T. Ryberg and A. Schulze \\ GeoForschungsZentrum Potsdam, Telegrafenberg 14473, Potsdam, Germany. \\ e-mail: jacek@gfz-potsdam.de; trond@gfz-potsdam.de; robert@gfz-potsdam.de
}

A. Lindeque,

GeoForschungsZentrum Potsdam, Telegrafenberg 14473, Potsdam, Germany.

AEON - Africa Earth Observatory Network, and Department of Geological Sciences, University of Cape Town, Rondebosch 7701, South Africa.

Council for Geoscience, Western Cape, PO Box 572, Bellville 7535, South Africa. e-mail: ansali@gfz-potsdam.de or alindeque@geoscience.org.za

\author{
M.H. Weber \\ GeoForschungsZentrum Potsdam, Telegrafenberg 14473, Potsdam, Germany. \\ Universität Potsdam, Institut für Geowissenschaften, Karl Liebknecht Strasse 24, 14476, \\ Potsdam, Germany. \\ e-mail: mhw@gfz-potsdam.de

\section{M.J. de Wit} \\ GeoForschungsZentrum Potsdam, Telegrafenberg 14473, Potsdam, Germany. \\ AEON - Africa Earth Observatory Network, and Department of Geological Sciences, \\ University of Cape Town, Rondebosch 7701, South Africa. \\ e-mail: maarten.dewit@uct.ac.za. \\ (c) 2007 September Geological Society of South Africa
}

\begin{abstract}
One of the projects within the framework of Inkaba yeAfrica, an earth system science initiative between German and South African research communities, is the Agulhas-Karoo transect. This $800 \mathrm{~km}$ north-south off-onshore transect runs from the offshore Agulhas Plateau onto the South African coast, across the Cape Fold Belt, Beattie Magnetic Anomaly, the Karoo Basin, the Great Escarpment and into the Kaapvaal Craton.

Among the number of geophysical measurements taken along the transect are two wide-angle on-shore seismic lines collected in April and May 2005. The lines run roughly parallel to each other approximately $200 \mathrm{~km}$ apart, starting at Mossel Bay and St. Francis, and running about $200 \mathrm{~km}$ north to Fraserburg and Graaf Reinet, respectively. At each line 48 seismic receivers were used to record data from 13 shots.

The profiles cross a wide variety of geological terrains, such as the siliciclastic sequences of the Paleozoic - Mesozoic Karoo and Oudtshoorn basins, the lower Paleozoic Cape Fold Belt, and the Eocambrian Kango and Kaaimans inliers. They also cross the Beattie Magnetic Anomaly, a large east-west orientated crustal feature within the upper crust, and more than $1000 \mathrm{~km}$ long, first reported almost a century ago, but still not fully understood.

The overall quality of seismic data is very good. First (P-wave) arrivals were manually picked on the available traces, and tomographic inversion was done using these travel times. The ray coverage made it possible to create the P-wave velocity model to depths of up to $25 \mathrm{~km}$. We find excellent correlation of the shallow features with surface rock type. Deeper down we can identify both stratigraphic and tectonic contacts between geological groups. These include an inferred possible blind Paleozoic thrust fault, and the unconformity between the Cape Supergroup and the Namaqua-Natal Metamorphic Complex. The normal listric geometry of the Kango and Gamtoos Faults is clearly seen to a minimum depth of $15 \mathrm{~km}$. We also observe a high velocity anomaly within the NNMC at $\sim 10 \mathrm{~km}$ depth that we relate to the source of the Beattie Magnetic Anomaly.
\end{abstract}

\section{Introduction}

Numerous studies of the crustal and upper mantle structures beneath southern Africa were performed during and since the Kaapvaal Craton Seismic Experiment (Carlson et al., 1996). While the depth of the Moho discontinuity across the subcontinent has received a lot of attention (e.g., Harvey et al., 2001; Nguuri et al., 2001; Stankiewicz et al., 2002), as have upper mantle discontinuities (e.g. James et al., 2001; Silver et al., 2001;
Gao et al., 2002; Stankiewicz et al., 2002; Fouch et al., 2004; Hamilton et al., 2006), less attention has been given to resolving individual structures inside the crust, particularly in regions flanking the Archaean Kaapvaal Craton. Poisson's ratio analyses (Stankiewicz et al., 2002; Nair et al., 2006) have shed light on crustal structure, but these also treat the whole crust as an integrated unit.

In the framework of the multi-disciplinary Inkaba yeAfrica project, a number of geophysical experiments 


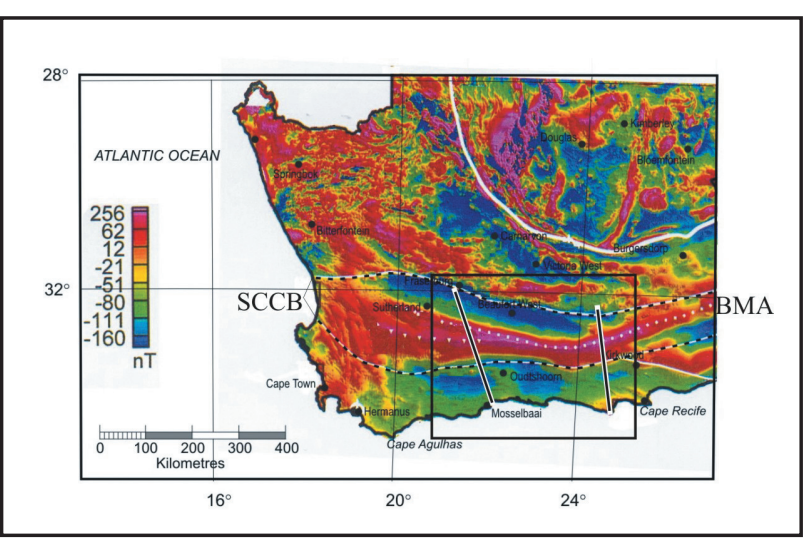

Figure 1. Location of the two on-shore profiles (black lines) superimposed on the total magnetic anomaly map of Barrett (1993). Black rectangle shows the margins of Figure 2. White squares mark the peak of the Beattie Magnetic Anomaly (BMA), with white triangles showing it's possible branching. White-black steeples mark the edges of the Southern Cape Conductive Belt (SCCB). White line marks the edge of the Kaapvaal Craton.

have been carried out in southern Africa and its surrounding oceans since 2004, and more are planned (de Wit and Horsfield, 2006). One of the experiments consisted of two approximately parallel on-off shore seismic profiles, carried out in April 2005 across the Southern Cape to the Agulhas Plateau, set up to perform a detailed analysis of the crust underlying this region using wide-angle seismics. This is the first time a deep seismic profile has been attempted in this region, though it must be mentioned that Green and Durrheim (1990) performed a seismic refraction experiment in northwestern South Africa using five shotpoints and 15 receivers. Here we examine the on-shore sections of the two profiles (Fraserburg to Mossel Bay, and Graaff Reinet to St. Francis, Figures 1 and 2) which were $240 \mathrm{~km}$ and $210 \mathrm{~km}$ in length, respectively. For each profile 48 seismic stations have been deployed. Every station consists of a GPS synchronized, 24 bit seismic data logger and a three-component seismic sensor (4.5 Hz). The digitization was done with 100 samples per second continuously, and later, during data processing, time series were cut out according to the actual shot time. Along each profile, 13 shots were fired in boreholes. Each 'shot' was actually made up of two identical charges detonated simultaneously in twin boreholes. The depth varied from 20 to 30 metres at the 13 locations, with charges between 75 and $125 \mathrm{~kg}$. The shot time was determined by GPS synchronized equipment, resulting in shot time accuracy of better that $1 \mathrm{~ms}$. The average shot spacing was thus approximately $20 \mathrm{~km}$, with receivers $5 \mathrm{~km}$ apart on average. The complementary off-shore sections are currently being analyzed at the Alfred Wegener Institute (e.g. Parsiegla et al., 2006; 2007), while magnetotelluric profiles roughly following the on-shore seismic lines are described elsewhere (Weckmann et al., 2007a; b). The joint integration of these datasets is in progress, and will be presented elsewhere.
In the study presented here, first arrivals (P-waves) at each shot were manually picked. These travel times were input into a modified version of FAST (Zelt and Barton, 1998). This programme uses the algorithm of Vidale (1988) to perform tomographic inversion of these travel times and produce a 2-dimensional P-wave velocity model of the crust. With the profile lengths used here, available ray coverage enables us to measure seismic velocities down to a depth of $25 \mathrm{~km}$ in the middle parts of the profile.

\section{Profile Setting}

The surface geology underlying the two profiles is shown in Figure 2. Both profiles start (in the north) on top of the Great Escarpment, about $30 \mathrm{~km}$ north of this geomorphic feature, in the Beaufort Group siliclastic sandstones and mudstones intruded by Jurassic Karoo dolerites. Further south the dolerites taper out, and two other groups of the Karoo Supergroup are crossed, the siliclastic turbidite deposits of the Ecca Group and the Dwyka glacial tillites with its overlying carbonaceous black shales of the Whitehill and Prince Albert Formations. The profiles also cross the Cape Supergroup, first the Witteberg and Bokkeveld Groups, and then the steep dipping quartzite ridges of the Cape Fold Belt (Swartberg and Outeniqua mountains on the western profile, Groot Winterhoek on the eastern profile) on the way to the coast, as well as the Jurassic Uitenhage Group. The western profile is more varied, as it also crosses two Late Neoproterozoic-Cambrian inliers: Kango and Kaaimans, as well the $\sim 540$ to $\sim 520$ Ma Cape Granite Suite in the extreme south near the coast at George.

An important geophysical feature intersecting the profiles is the Beattie Magnetic Anomaly (BMA). First reported by Beattie (1909), this positive static magnetic anomaly stretches for more than $1000 \mathrm{~km}$ in a roughly east-west orientation (Figure 1). De Beer and Gough (1980) used Curie isotherms to show the anomaly must have a crustal source. Pitts et al. (1992) suggested that a body stretching from $7 \mathrm{~km}$ below the surface up to a depth of $\sim 30 \mathrm{~km}$ is necessary to account for the anomaly. They suggested serpentinised oceanic crust as the source, but a recent magnetotelluric survey (Weckmann et al., 2007a) found no evidence for such a body. Harvey et al. (2001) used receiver functions to identify two crustal discontinuities in the region where the anomaly is observed, at depths of 7 to 11 and 17 to $19 \mathrm{~km}$, respectively, and suggested these are upper and lower boundaries of a body responsible for the anomaly.

Another east-west extending structure in the region is a zone of electrically conductive material beneath the southern Karoo basin and frontal Cape Fold Belt. This Southern Cape Conductive Belt (SCCB) was first noted by Gough et al. (1973), who suggested the conductive material is in the crust. A link between the SCCB and BMA was suggested almost immediately afterwards (de Beer et al., 1974), but this is refuted by 


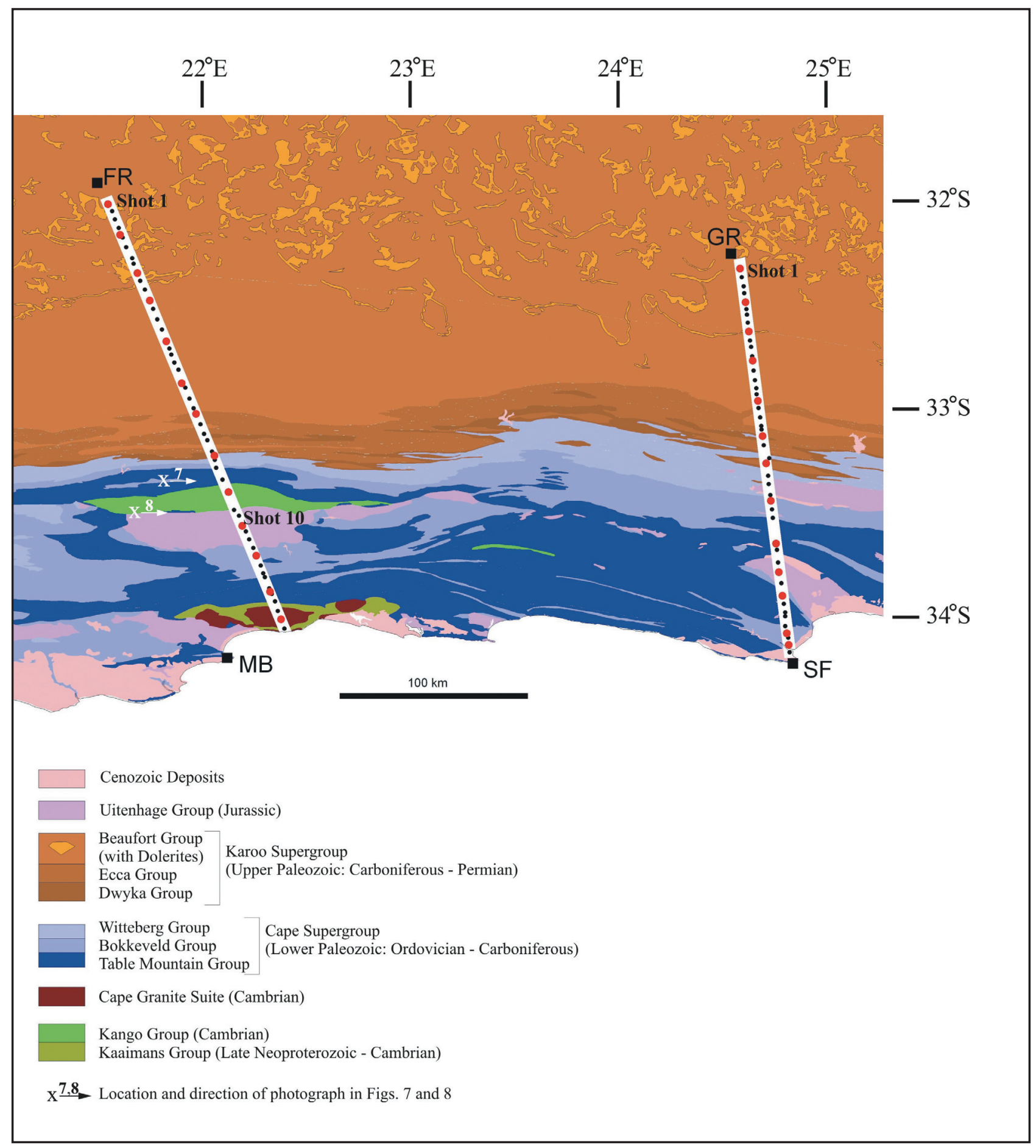

Figure 2. Geological map of the region of interest. The two profiles are shown in detail, with black dots showing the receivers, and red circles the shot points. Black squares mark the towns near the profiles' edges: FR - Fraserburg, MB - Mossel Bay, GR - Graaf Reinet, $\mathrm{SF}-\mathrm{St}$ Francis.

the recent detailed magnetotelluric work of Weckmann et al. (2007b).

\section{Data Processing and Tomography}

The quality of the seismic data obtained is very good. Direct or refracted arrivals of P-waves are clearly visible in most traces recorded by the receivers, and were manually picked. 420 travel times have been picked for the data from the western profile, and 439 from the eastern - this corresponds to more than $70 \%$ of total recorded traces. Examples of the data are shown in Figure 3. Secondary phases can also be identified in the traces, some of which can be seen in the examples, but these have not been incorporated into this initial study.

A standard 2-dimensional tomographic inversion method involves dividing the cross-section beneath the length of the profile into rectangular cells. An initial velocity model has to be provided, and its values are temporarily assigned to the cells. Synthetic travel times between each source and receiver are then 

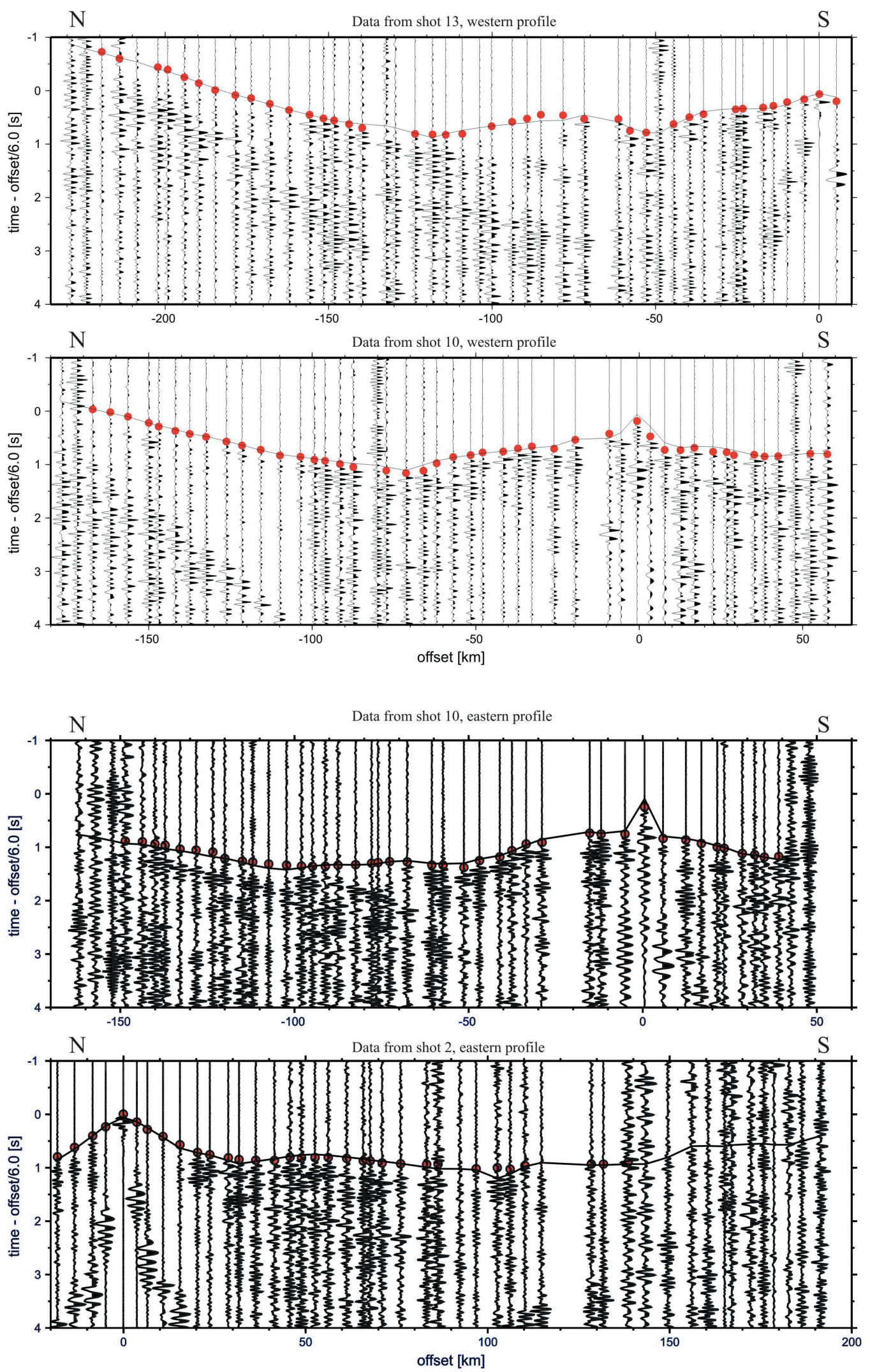

Figure 3. Examples of the data collected during the experiment. Trace normalized vertical components of the data recorded from the two shots for each profile. The shot points used for presentation here are marked with red circles on Figure 4 . Traces were time reduced so arrivals of a wave with velocity of $6 \mathrm{~km} / \mathrm{sec}$ would appear horizontal. Red dots show the manual picks, while the black trace shows the travel times one would expect from the computed model. 

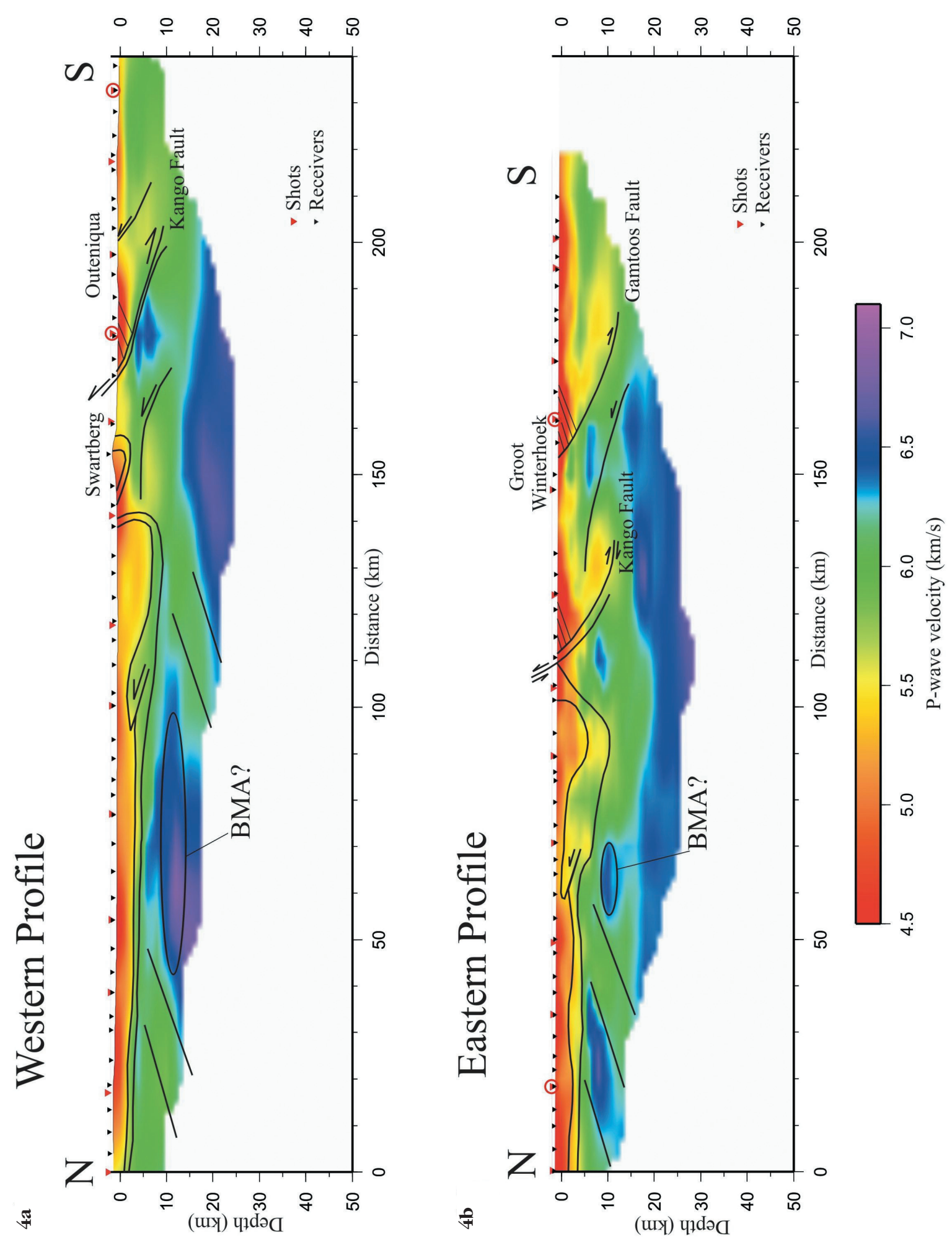

Figure 4. The P-wave velocity models computed for the (a) western and (b) eastern profiles. Left margins of the diagrams correspond to the northern edges of the profiles, and yellow-red colours represent slower velocities. Shot points and receivers have been marked on the surface with red and black triangles, respectively - these correspond to circles of the same colours in Figure 2 . Depth is given in km, as is horizontal length along the profile. The topography has been preserved, so features like the Swartberg can be seen. A number of features has been marked - these are discussed in the text with the aid of Figure 6. The circled shot locations are the examples from Figure 3. RMS errors between observed travel times and synthetic ones each model would produce are $52.5 \mathrm{~ms}$ for the western profile, and $36.3 \mathrm{~ms}$ for the eastern. 

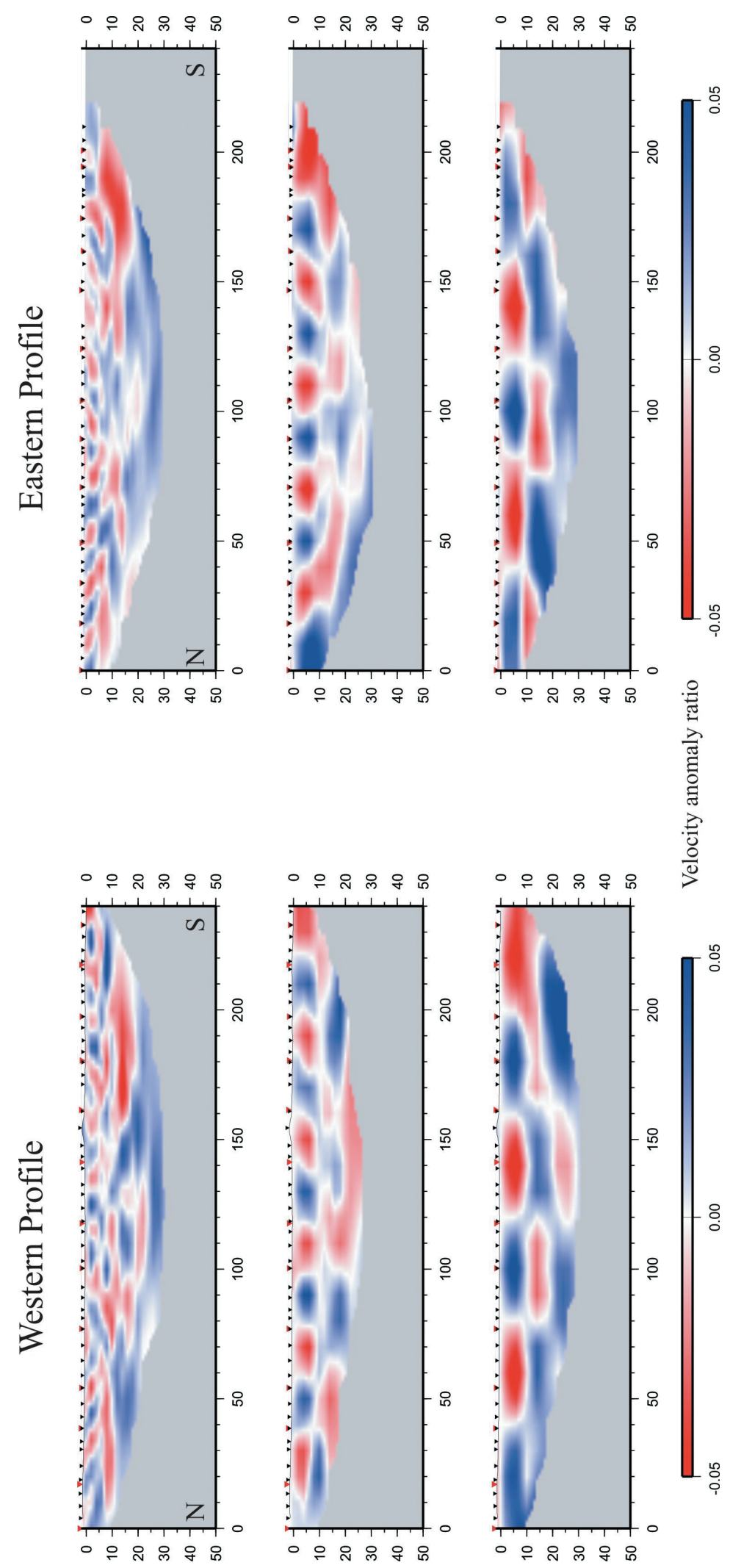

Figure 5. Resolution tests of the models, examining what combination of size and depth allow for a confident identification. Three different checkerboards are used for both the western (left) and eastern (right) profile. Topography, shot and receiver positions have been included, as in Figure 4. Size of original anomalies: Top row: $10 \mathrm{~km}$ (horizontal) by $5 \mathrm{~km}$ (vertical); middle: $20 \mathrm{~km}$ by $10 \mathrm{~km}$; bottom: $40 \mathrm{~km}$ by $10 \mathrm{~km}$. Amplitude of velocity anomalies is $5 \%$ 
computed, and compared to the real (picked) ones. Vidale (1988) derives an algorithm for how the velocity values in individual cells can be adjusted to minimize the difference between these synthetic and real travel times.

The 2-D technique was further modified by Zelt and Barton (1998) in such a way that high velocity contrasts are easier to detect. These authors released a software package FAST (First Arrival Seismic Tomography), which performs iterations of this calculation to compute a stable model. This package was used in our study.

An obvious disadvantage of the method described above is the necessity to provide a reasonable starting model. Put differently, the velocity model we are trying to produce is dependent on our first guess at it. To minimize the importance of the accuracy of this first guess, an iterative approach varying cell sizes has been developed (also discussed in Ryberg et al., 2007). In this approach, the initial cell size is made vary large, for example the cross-section is divided into six cells along its length, and four along depth, and a fairly straightforward initial model is provided. FAST software is then used to run an inversion; the resulting 'velocity model' is obviously too coarse for any sort of analysis, but is used as the starting model for the next iteration, which uses smaller cell sizes. Five such iterations were performed in this study, the final velocity model being given in $2 \mathrm{~km}$ (horizontal) by $1 \mathrm{~km}$ (vertical) cells.

\section{Results and Reliability}

The final velocity models for the two profiles are shown in Figure 4. Apart from the unsurprising increase of velocity with depth, a number of other features are clearly visible, some of which have been highlighted with black lines, and are discussed later. However, before any features can be discussed, it is important to understand the resolving capabilities of the model. This is done by applying "checkerboard tests". In these tests a checkerboard of alternate positive and negative velocity anomalies is added to the initial velocity model. Synthetic travel times are then generated, and an inversion is performed using these times. The inversion result is then compared to the initial model. If the blocks can be observed in the final model, we can assume that a real feature corresponding to the block's size and position would be resolved, and a feature like that in our model is likely to be real, and not a modeling artifact. Different size checkerboards were used here. Results for three different ones are shown for each profile in Figure 5. As might have been expected, resolving capabilities decrease with both decreasing block size and increasing depth. Structures $10 \mathrm{~km}$ across can only be resolved near the surface, with features needing to be $\sim 40 \mathrm{~km}$ across to be confidently identified anywhere in the model. Similarly, vertical resolution also varies with depth: a body a few $\mathrm{km}$ thick can be resolved near the surface, but not necessarily at a greater depth.

\section{Discussion and Interpretation}

The interpretation lines used to sketch features of the models in Figure 4 are reproduced in Figure 6 without the velocities. End Paleozoic thrusts related to the

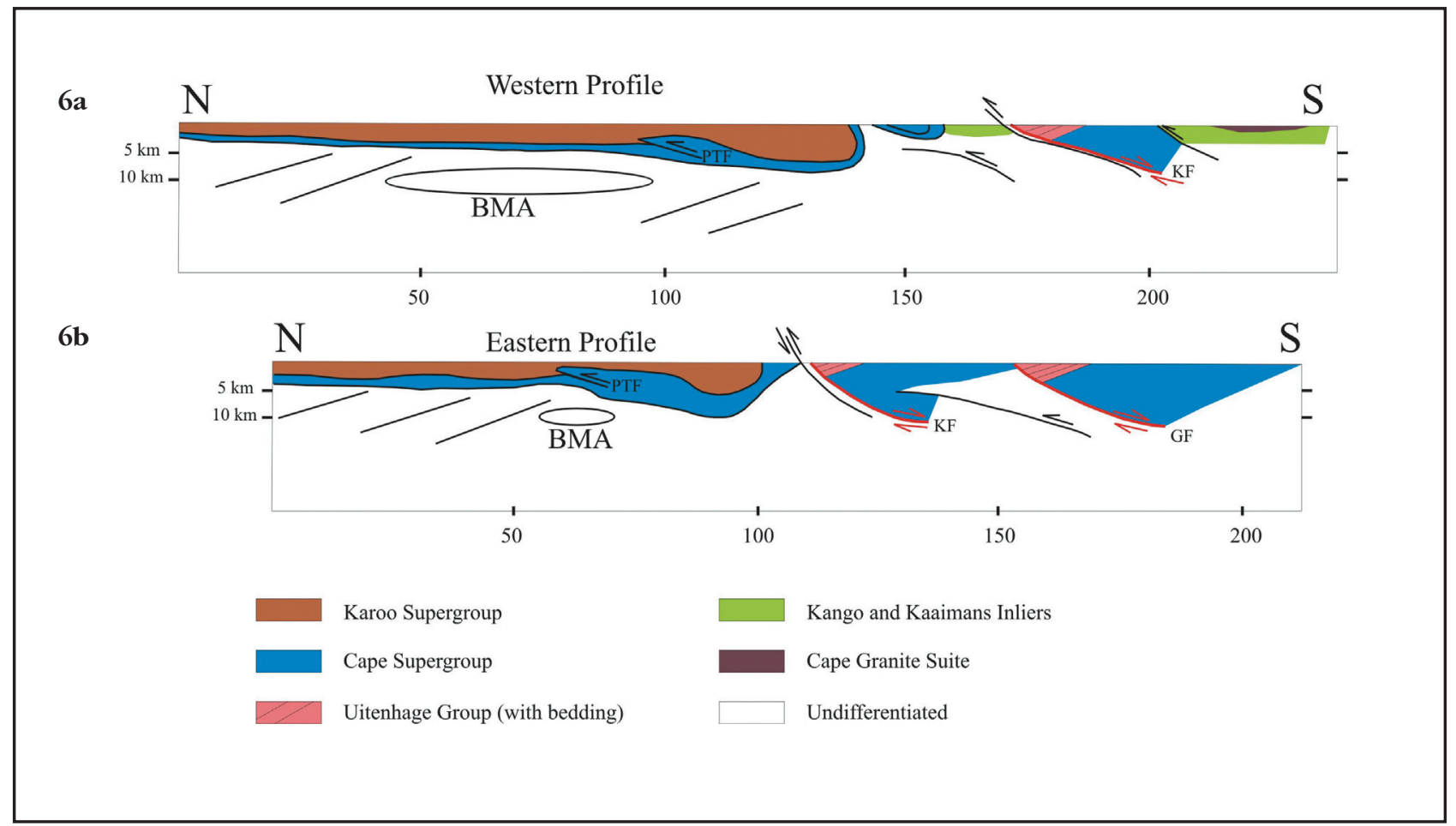

Figure 6. Geological interpretation of features in Figure 4: (a) western profile; (b) eastern profile. Mesozoic normal faults $(\mathrm{KF}=\mathrm{Kango}$ Fault, GF = Gamtoos Fault) have been marked in red to distinguish them from Paleozoic thrusts. The blind Paleozoic thrust fault discussed in the text is marked PTF. Colouring similar to the legend of Figure 2. 


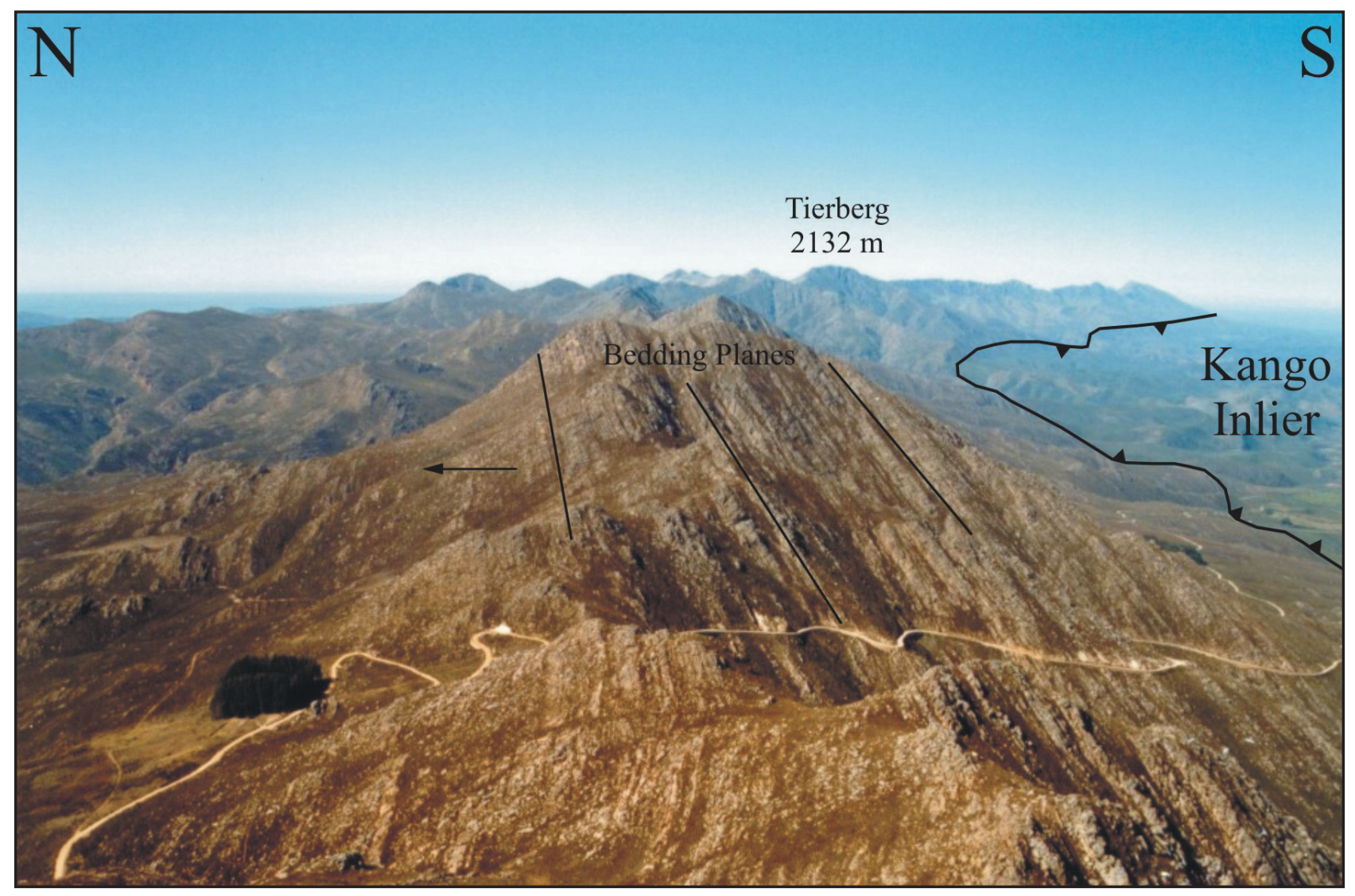

Figure 7. Photograph of Swartberg Pass illustrating the overturned ridges of the Table Mountain Group quartzites. Arrow marks the 'way up' of quartzites. Taken from an unnamed 1948 metre spot height immediately west of the Pass, facing east (see Figure 2 for location).

250 Ma formation of the Cape Fold Belt have been left black, while Mesozoic listric normal faults related to the subsequent break-up of Gondwana at 130 Ma have been changed to red to emphasize the difference. The latter in particular, are well know from geology and off-shore seismic reflection data derived from petroleum exploration (e.g. Paton et al., 2006). The colours used to illustrate the depth distribution of different rocks match those on the geological map from Figure 2 (though the Karoo and Cape Supergroups are not subdivided into Groups here).

Both profiles have their northern halves in the Karoo Supergroup. These rocks are characterized by slow ( 4.6 to $5.3 \mathrm{~km} / \mathrm{s}$, red and orange in Figure 4) seismic velocities. This Supergroup extends less then $5 \mathrm{~km}$ deep beneath most of its outcrop, consistent with the results of the seismic reflection experiment that partially coincides with the western profile (Lindeque et al., 2006; 2007, this volume), with magnetotelluric experiments that coincide with both our profiles (Weckmann et al., 2007a; b), and with depth to basement found in many boreholes in the Karoo basin (e.g. Eglington and Armstrong, 2003). The exception is the notable thickening of the basin towards the tectonic front of the Cape Fold Belt, and where the Cape-Karoo succession is the thickest, just inside the large asymmetric synform immediately north of the first steeply dipping to overtuned outcrops of the Witteberg
Group (at $\sim 140 \mathrm{~km}$ in the western profile, and $\sim 100 \mathrm{~km}$ in the eastern; e.g. Cole, 1992; Harvey et al., 2001). This is consistent with extrapolated geological crosssections, in which the large overturned limb of the synform marks the approximate location of the most northerly exposed thrusts of the Cape Fold Belt (e.g., Cole, 1992; Craddock et al., 2007). In both seismic profiles the low-velocity band corresponding to the Karoo Group becomes very thin $(<2 \mathrm{~km})$ around $40 \mathrm{~km}$ north of the first Witteberg outcrop. We interpret this as a possible blind Paleozoic Thrust Fault (PTF in Figure 6) related to the Cape Orogeny, but this is poorly constrained.

The Cape Fold Belt deforms mostly the Cape Supergroup that comprises predominantly quartzites of greater density $\left(\sim 2800 \mathrm{~kg} / \mathrm{m}^{3}\right)$ than the sandstone-shale sequence that makes up the Karoo Supergroup $(\sim 2500$ $\mathrm{kg} / \mathrm{m}^{3}$, Meissner, 1986). We therefore suggest the higher seismic velocities $(5.4$ to $5.8 \mathrm{~km} / \mathrm{s}$, yellow - pale green) observed mark the location of the Cape Supergroup rocks within the Cape Fold Belt. The subsurface geology structure of this Belt is very complicated and not known in detail, and the resolution of this experiment is not sufficient to shed more light on it. We do, however, know from field observations that the bedding of the sedimentary rocks of the Karoo and Cape Supergroups is folded into a regional-scale asymmetric crustal fold overturned to the north that can be traced across the 


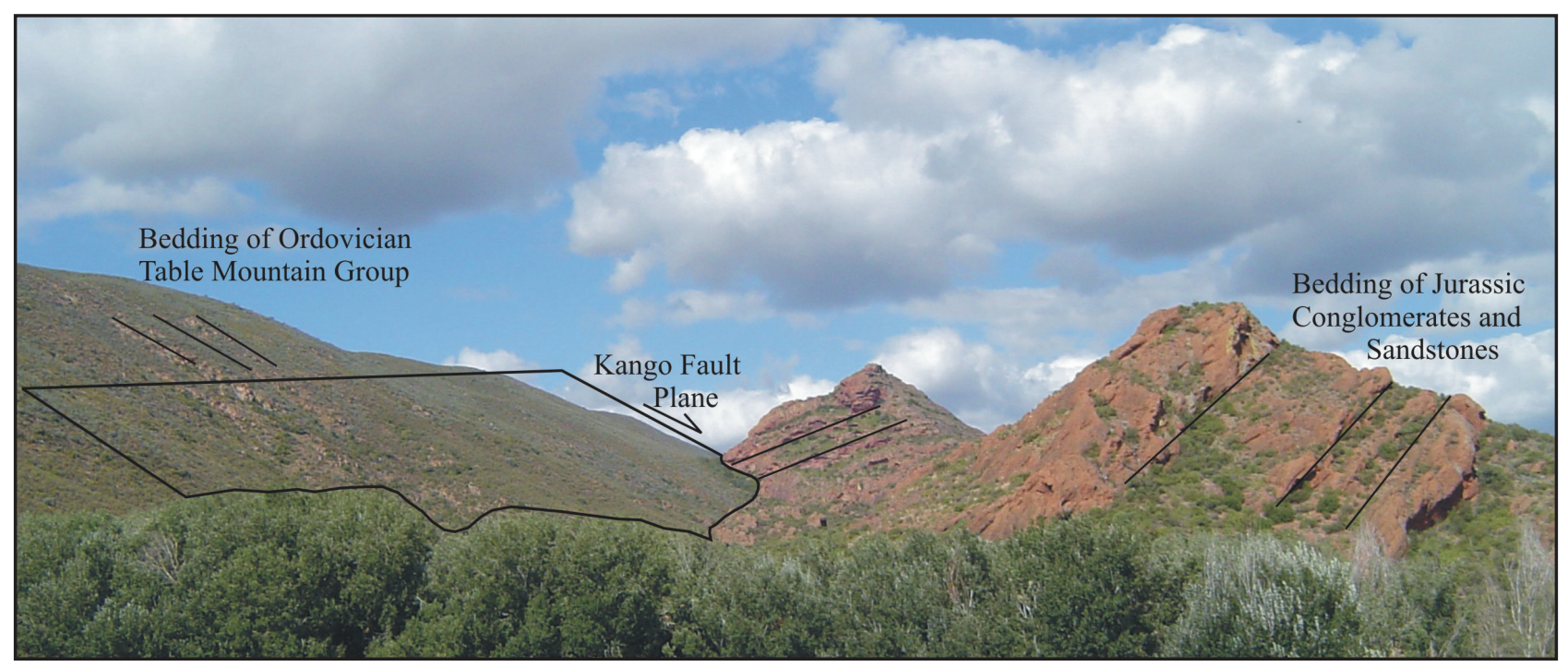

Figure 8. Photograph of the Kango Fault near to its intersection with the western profile. To the left of the fault: Table Mountain Group quartzites unconformably overlying Neoproterozoic - Cambrian conglomerates and quartzites, with bedding nearly parallel to the Kango Fault. To the right of the fault: Jurassic sandstones and conglomerates, with bedding dipping into and cut off by the low angle normal fault. Taken from Red Stone Hills settlement off the R62 near Calitzdorp, facing east (see Figure 2 for location).

entire Swartberg Mountain Range and which is especially spectacular near the Swartberg Pass, where the western profile crosses the mountains (Figure 7; see also sections in Hälbich 1983; 1993). We can therefore confidently sketch this overturn in Figure 6. Our results also suggest that while the Cape Supergroup underlies the Karoo Supergroup all the way to the northern edge of the study area, consistent with subsurface geology from borehole data (e.g. CR 1/68; Eglington and Armstrong, 2003), the possible Paleozoic Thrust Fault would mark the most northern influence of shortening deformation in the upper crust related to the Cape Orogeny. The lower boundary of the Cape Supergroup forms an unconformity with the Mesoproterozoic Namaqua-Natal Metamorphic Complex (NNMC), as is more clearly displayed on the seismic reflection profile reported on by Lindeque et al. (2007). In this NNMC basement, we find suggestions of north dipping tectonic fabric, as illustrated in Figures 4 and 6. Again, this is displayed with greater clarity in the reflection line (Lindeque et al., 2007).

Farther south, in the eastern profile, two clear velocity anomalies are observed. Their geometry and size relative to checkerboard tests (Figure 5) leads us to interpret them as two Mesozoic normal faults, the Kango Fault and the Gamtoos Fault. These faults separate the NNMC from more recent sedimentary rocks down to a depth of $15 \mathrm{~km}$ in asymmetric listric basins (de Wit, 1992). The western profile only crosses the Kango Fault (Figure 8), which is not as clearly visible. Near surface the hanging walls of the faults mark the northern boundary of the outcrops of the Jurassic Uitenhage Basin with its very slow seismic velocity $(\sim 4.5 \mathrm{~km} / \mathrm{s}$, red in Figure 4), whilst the footwall comprises of denser quartzites. The bedding of these outcrops, measured from surface geology, has been indicated with thin lines.
As was mentioned earlier, the profiles cross the Beattie Magnetic Anomaly. While the magnetic anomaly is as much as $100 \mathrm{~km}$ wide, whatever body is responsible for it is likely to be much more narrow. In each of the velocity models presented here, there exists a high velocity region at depths of $10-15 \mathrm{~km}$ (marked with black ellipses) directly beneath the highest intensity of the BMA. In the eastern profile this region is approximately $20 \mathrm{~km}$ wide (between 50 and $70 \mathrm{~km}$ along the profile), while in the western one it reaches $70 \mathrm{~km}$ in width (from 40 to $110 \mathrm{~km}$ ). Very close to its intersection with the western profile the BMA becomes much wider to the west (Figure 1), and possibly splits into two branches (Harvey et al., 2001), further suggesting that these high velocity zones are directly related to the BMA.

An interesting feature of the western profile is the lack of seismic signals from the Cape Granite and the Late Neoproterozoic - Cambrian inliers. These granites are known from surface geology but are not obviously visible in the seismic section, and therefore may be thin sheets or sills, and are certainly not major features at depth. This is consistent with the field observations of Barnett et al. (1997), that indicate that the rocks of these Neoproterozoic inliers are predominantly sedimentary rocks that form part of the lowermost sections of the Cape Supergroup. The existence of a high velocity zone just beneath some of the granites (up to $6.2 \mathrm{~km} / \mathrm{s}$ at depth of just $5 \mathrm{~km}$ ) is indicative of highly metamorphosed rocks of the NNMC. In turn this suggests the presence of major Cape orogenic-age (e.g. $\sim 250$ Ma) south-dipping thrust faults, with northward transport directions, in this region, as has been previously suggested (Hälbich, 1983; 1993; Paton et al., 2006). As we cannot see the extent of these structures in our model, their 
depth in Figure 6a is conjectural, and no lower bounds have been indicated.

A number of features visible in Figure 4 have not been discussed here. Some of them, such as the small high velocity 'blob' at $10 \mathrm{~km}$ depth $110 \mathrm{~km}$ along the eastern profile, push the resolving capabilities to the limit, and could be artifacts of the model. On the other hand this feature is suggestive of NNMC crust brought close to the surface by an early thrust fault as sketched in the section. The northward dipping tectonic fabric of the NNMC is therefore most likely related to earlier Mesoproterozoic subduction/accretion of exotic and suspect terranes, within a north dipping palaeosubduction zone outboard of the tectonically active margin of southern Africa at that time (in many models this was part of the active margin of the Rodinia supercontinent (e.g. Hoffman, 1991; Unrug, 1996; Meert, 2003; Eglington and Armstrong, 2003)).

It is interesting to compare our study area to northwestern Canada, where the parallels to the Kaapvaal Craton, Cape Orogeny and the Karoo Basin are striking. In that region the Archaean Slave Craton forms the geological core of that region, against which subsequent blocks were tectonically accreted. To the west and southwest of the craton, the Wopmay orogen lies beneath the sediments of the Western Canada Sedimentary Basin (e.g., Clowes et al., 2005). It is therefore worthwhile to compare our results to those of a seismic experiment of Clowes et al. (2005) in Canada. The velocity models of both studies turn out to have some similar features. The slowest velocities in the Canadian model are $<4.7 \mathrm{~km} / \mathrm{s}$, at the outcrop of the Jurassic Bowser Basin - compare this to the $4.5 \mathrm{~km} / \mathrm{s}$ we found in the Jurassic Uitenhage Group. In the upper $10 \mathrm{~km}$ of the Canadian crust, velocities vary between 5 and $6.5 \mathrm{~km} / \mathrm{s}$, the variations indicating the geometry of the underlying orogen. The average velocity at a depth of $20 \mathrm{~km}$ is approximately $6.5 \mathrm{~km} / \mathrm{s}$. Other studies of northwestern Canada (e.g., Fernandez-Viejo and Clowes, 2003; Cook and Erdmer, 2005) produce similar results, and these patterns are very similar to the ones obtained by us for southern Africa.

\section{Summary and Conclusions}

In this study we have used tomographic inversion of seismic data to compute P-wave velocity models for the upper crust beneath the southern margin of South Africa. A number of the models' features agree with what might have been expected from a knowledge of the area's geological setting and geophysical measurements. North of the Cape Fold Belt we see the Karoo Supergroup lying over the Cape Supergroup. The Cape-Karoo Supergroup sequences thicken considerably at the front on the Cape Fold Belt (which could be related to tectonic duplications), and taper out in a large asymmetric synform. We see the relatively dense quartzites of the Cape Fold Belt, but their complicated structure cannot be resolved at our experiment's resolution. Farther south we see the geometry of the listric normal Kango and Gamtoos Faults, that separate the Cape Supergroup and Namaqua-Natal Metamorphic Complex from more recent sedimentary rocks.

Other features of our models are previously undocumented, and can help to derive a more complete tectonic description of the region. In particular, we see suggestions for a blind Paleozoic Thrust Fault possibly relating to the Cape Orogeny well within the Karoo basin domain. We also identify seismic velocity anomaly regions that we relate to the Beattie Magnetic Anomaly.

A detailed description of the structure of the crust underlying the Southern Cape cannot be provided using solely the velocity models obtained here. Instead, the results should be viewed in the framework of the ongoing Inkaba ye Africa project. As part of this project, other geophysical experiments have been conducted in the region. These include a reflection seismic experiment along a profile partially coinciding with the western one from this study. Preliminary results of that project (Lindeque et al., 2006; 2007) have identified multiple environments with distinct, characteristic reflectors, that better reveal the complex tectonic history of both the NNMC basement and the frontal ranges of the Cape Fold Belt. Correlation of those results with the velocity model, in particular in the region of the BMA, are in progress.

It was also mentioned earlier that the profiles used here are complemented by off-shore experiment carried by the Alfred Wegener Institute (Parsiegla et al., 2006; 2007). Combining the on- and off-shore data will increase the sounding depth and resolution of both experiments. This work is currently in progress.

Another important aspect of Inkaba ye Africa is a series of magnetotelluric (MT) experiments have been conducted (Weckmann et al., 2006; 2007a; b), also partially coinciding with the locations of seismic profiles. These studies provide information on electrical resistivity of sub-surface structures. This quantity is independent of seismic velocity, and therefore provides an additional constraint in crustal feature identification. A probabilistic approach to combine the two quantities has been developed by Bedrosian et al. (2007). A crosscorrelation of independently computed parameters yields a probability density function. Classes can then be identified as regions of enhanced probability, and remapped on either (or both) depth sections. Such a joint interpretation is currently in progress.

\section{Acknowledgements}

JS and AL thank the GeoForschungsZentrum Potsdam for providing scholarships to conduct their research in Potsdam as part of the capacity building program of the Inkaba yeAfrica project. We thank Ron Clowes and Mark Muller for constructive and extensive reviews of an earlier version of the manuscript. The seismic experiment was funded by the GFZ, with equipment coming from the Geophysical Instruments Pool, Potsdam. All the farmers who granted us access to their 
land are thanked for their cooperation, as is the Council for Geoscience. This is AEON contribution 36 and Inkaba yeAfrica contribution number 19.

\section{References}

Barnett, W., Armstrong, R and de Wit, M.J. (1997). Stratigraphy of the upper Neoproterozoic Kango and lower Paleozoic Table Mountain groups of the Cape fold belt revisited. South African Journal of Geology, 100, 237-250. Barrett, S.D. (1993). The African Mapping Project. International Institute for Aeorospace Surveys and Earth Sciences, Special Issue, 1993-2, 122-131.

Beattie, J.C. (1909). Report of a magnetic survey of South Africa. Royal Society of London Publication, Cambridge University Press, London, 235pp. Bedrosian, P.A., Maercklin, N., Weckmann, U., Bartov, Y., Ryberg, T. and Ritter, O. (2007). Lithology-derived structure classification from the joint interpretation of magnetotelluric and seismic models. Geophysical Journal International, in press, doi: 10.1111/j.1365-246X.2007.03440.x.

Carlson, R.W., Grove, T.L., de Wit, M.J. and Gurney, J.J. (1996). Program to study crust and mantle of the Archaean Craton in Southern Africa American Geophysical Union, EOS, 77, 273-277.

Clowes, R.M., Hammer, P.T.C., Fernandez-Viejo, G and Welford, J.K. (2005). Lithospheric structure in northwestern Canada from Lithoprobe seismic refraction and related studies: a synthesis. Canadian Journal of Earth Sciences, 42, 1277-1293.

Cole, D.I. (1992). Evolution and development of the Karoo Basin. In: M. J de Wit and I. G. D. Ransome (Editors), Inversion Tectonics of the Cape Fold Belt, Karoo and Cretaceous Basins of Southern Africa, Balkema, Rotterdam, The Netherlands, 87-99.

Cook, F.A. and Erdmer, P. (2005). An $1800 \mathrm{~km}$ cross section of the lithosphere through the northwestern North American plate: lessons from 4.0 billion years of Earth's history. Canadian Journal of Earth Sciences, 42, 1295-1311.

Craddock, J.P., Alex W. McKiernan, A.W. and de Wit, M.J. 2007. Calcite Twin Analysis in Syntectonic Calcite, Cape Fold Belt, South Africa: Implications for Fold Rotation and Cleavage Formation within a shallow thrust front. Journal of Structural Geology, 29(7), 1100-1113.

De Beer, J.H., Van Zyl, J.S.V. and Bahnemann, F.K. (1974). Plate tectonic origin for the Cape Fold Belt? Nature, 252, 675-676

De Beer, J.H. and Gough, D.I. (1980). Conductive structures is southernmost Africa: A magnetometer array study. Geophysical Journal of the Royal Astronomical Society, 63, 479-495.

De Wit, M.J., (1992). The Cape Fold Belt: A Challenge for an integrated approach to inversion tectonics. In: M. J. de Wit and I. G. D. Ransome (Editors), Inversion Tectonics of the Cape Fold Belt, Karoo and Cretaceous Basins of Southern Africa, Balkema, Rotterdam, The Netherlands, 3-12.

De Wit, M.J. and Horsfield, B. (2006). Inkaba ye Africa Project surveys sector of Earth from Core to Space. American Geophysical Union, EOS, 87, 11

Eglington, B.M. and Armstrong, R.A. (2003). Geochronological and isotopic constraints on the Mesoproterozoic Namaqua-Natal Belt: evidence from deep borehole intersections in South Africa. Precambrian Research, 125, 179-189.

Fernandez-Viejo, G. and Clowes, R.M. (2003). Lithospheric structure beneath the Archaean Slave Province and Proterozoic Wopmay orogen, northwestern Canada, from a Lithoprobe refraction / wide angle reflection survey. Geophysical Journal International, 153, 1-19

Fouch, M.J., James, D.E., VanDecar, J.C. and van der Lee, S. (2004). Mantle seismic structure beneath the Kaapvaal and Zimbabwe Cratons. South African Journal of Geology, 107, 33-44

Gao, S.S., Silver, P.G. and Liu, K.H. (2002). Mantle discontinuities beneath Southern Africa. Geophysical Research Letters, 29, doi: 10.1029/2001GL013834.

Gough, D.I., De Beer, J.H. and Van Zyl, J.S.V. (1973). A magnetometer array study in southern Africa. Geophysical Journal of the Royal Astronomical Society, 34, 421-433.

Green, R.W.E. and Durrheim, R.J. (1990). A Seismic Refraction Investigation of the Namaqualand Metamorphic Complex, South Africa. Journal of Geophysical Research, 95, B12, 19,927-19,932.

Hälbich, I.W. (1983). A Tectogenesis of the Cape Fold Belt. Special Publication of the Geological Society of South Africa, 12, 165-175.

Hälbich, I.W. (1993). Cape Fold Belt - Agulhas Bank Transect across Gondwana suture in Southern Africa. American Geophysical Union Special
Publication, 202, 18pp.

Hamilton, M.P., Jones, A.G., Evans, R.L., Evans, S., Fourie, C.J.S., Garcia, X., Mountford, A. and Spratt, J.E. (2006). Electrical anisotropy of South African lithosphere compared with seismic anisotropy from shear-wave splitting analyses. Physics of the Earth and Planetary Interiors, 158, 226-239.

Harvey, J.D., de Wit, M.J., Stankiewicz, J. and Doucoure, C.M. (2001). Structural variations of the crust in the Southwestern Cape, deduced from seismic receiver functions. South African Journal of Geology, 104, 231-242.

Hoffman, P.F. (1991). Did the Breakout of Laurentia Turn Gondwanaland Inside-Out? Science, 252, 1409-1412.

James, D.E., Fouch, M.J., Van Decar, J.C. and van der Lee, S. (2001). Tectospheric structure beneath southern Africa. Geophysical Research Letters, 28, 2485-2488.

Lindeque, A., Ryberg, T., Weber, M., deWit, M.J. (2006). Understanding the Beattie Magnetic Anomaly, Karoo Basin and Deep Crustal Tectonics of Southernmost Africa: Near Vertical Seismic Reflection Data of the Inkaba ye Africa Onshore-Offshore Agulhas-Karoo Geoscience Transect. American Geophysical Union, EOS Transactions, 87 (52)

Lindeque, A.S., Ryberg, T., Stankiewicz, J., Weber, M. and de Wit, M.J. (2007). Seismic imaging of the crust and Moho in a section across the Beattie Magentic Anomaly, South Africa. South African Journal of Geology, 110, $419-438$

Meert, J.G. 2003. A synopsis of events related to the assembly of eastern Gondwana. Tectonophysics, 362, 1-40

Meissner, R. (1986). The Continental Crust: A Geophysical Approach. International Geophysics Series, Academic Press, New York, United States of America, 34, Please give number of pages.

Nair, S.K., Gao, S.S., Liu, K.H. and Silver, P.G. (2006). Southern African crustal evolution and composition: Constraints from receiver function studies. Journal of Geophysical Research, 111 (B02304), doi: 10.1029/2005JB003802.

Nguuri T.K., Gore, J., James, D.E. and Webb, S.J., Wright, C., Zengeni, T.G., Gwavava, O. and Snoke, J.A. (2001). Crustal structure beneath southern Africa and its implications for the formation and evolution of the Kaapvaal and Zimbabwe cratons. Geophysical Research Letters, 28, 2501-2504.

Parsiegla, N., Gohl, K., Ritter, O., Weckmann, U., Ryberg, T., Stankiewicz, J., de Wit, M.J. and Uenzelmann-Neben, G. (2006). The Agulhas-Karoo Geoscience transect: Unravelling a billion year history of continental accretion and separation in Southern Africa. 12th International Symposium on Deep Seismic Profiling of the Continents and their Margins, Hayama, Japan, 24-29 September 2006

Parsiegla, N, Gohl, K. and Uenzelmann-Neben, G. (2007). Deep crustal structure of the sheared South African continental margin: first results of the Agulhas-Karoo Geoscience Transect. South African Journal of Geology, 110, 393-406

Paton, D.A., Macdonald, D.I.M. and Underhill, J.R. (2006). Applicability of this or thick skinned structural models in a region of multiple inversion episodes; southern South Africa. Journal of Structural Geology, 28, 1933-1947.

Pitts, B., Mahler, M., de Beer, J. and Gough, D. (1992). Interpretation of magnetic, gravity and magnetotelluric data across the Cape Fold Belt and Karoo Basin. In: M. J. de Wit and I. G. D. Ransome (Editors), Inversion Tectonics of the Cape Fold Belt, Karoo and Cretaceous Basins of Southern Africa, Balkema, Rotterdam, The Netherlands, 27-32.

Ryberg, T., Weber, M., Garfunkel, Z. and Bartov, Y. (2007). The shallow velocity structure across the Dead Sea Transform fault, Arava Valley, from seismic data. Journal of Geophysical Research, 112(B8) B08307.

Silver, P.G., Gao, S.S and Liu, K.H. (2001). Mantle deformation beneath southern Africa. Geophysical Research Letters, 28, 2493-2496.

Stankiewicz, J., Chevrot, S., van der Hilst, R.D. and de Wit, M.J. (2002). Crustal thickness, discontinuity depth, and upper mantle structure beneath southern Africa: Constraints from body wave conversions. Physics of the Earth and Planetary Interiors, 130, 235-251.

Unrug, R. 1996. The Assembly of Gondwanaland. Episodes, 19, 11-20.

Vidale, J.E. (1988). Finite-difference calculation of travel times. Bulletin of the Seismological Society of America, 78, 2062-2076.

Weckmann, U., Ritter, O., Branch, T., Jung, A., Stankiewicz, J., Becken, M. and de Wit, M.J. (2006). The Agulhas MT transect from the coast into the Craton - $600 \mathrm{~km}$ of South Africa's continental accretion processes American Geophysical Union, EOS Transactions, 87 (52) 
Weckmann, U., Ritter, O., Jung, A., Branch, T. and de Wit, M.J. (2007a). Magnetotelluric measurements across the Beattie magnetic anomaly and the Southern Cape Conductive Belt, South Africa. Journal of Geophysical Research, 112, B05416, doi: 10.1029/2005JB003975.

Weckmann, U., Jung, A., Branch, T. and Ritter, O. (2007b). Comparison of electrical conductivity structures and 2D magnetic modelling along two profiles crossing the Beattie Magnetic Anomaly, South Africa. South African
Journal of Geology, 110, 449-464

Zelt, C.A. and Barton, P.J. (1998). Three-dimensional seismic refraction tomography: A comparison of two methods applied to data from the Faeroe Basin. Journal of Geophysical Research, 103 (B4), 7187-7210.

Editorial handling: M. J. de Wit and Brian Horsfield 